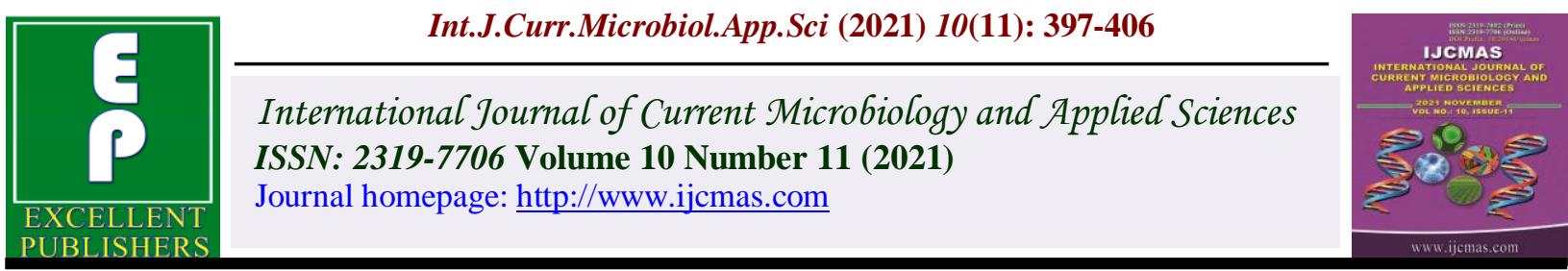

\title{
Aquaponics Systems: Future Food Production System
}

\author{
T. Suguna* \\ Fisheries Research Station, SVVU, Undi, W.G. Dt, Andhra Pradesh, India \\ *Corresponding author
}

\section{Keywords}

Aquaponics, hydroponics, recirculatory aquaculture system, fish, vegetables

\section{Article Info}

Received:

16 October 2021

Accepted:

04 November 2021

Available Online:

10 November 2021

\section{A B S T R A C T}

Aquaculture being the important source of global animal protein, is the potential food production sector. The ever increasing population worldwide, urbanization, human activities, environmental degradation, social and economic problems drive the need for new, innovative and improved solutions for food production. One pioneering approach that promises to address these problems is Aquaponics. Aquaponics is the integration of recirculatory aquaculture system and hydroponics in one production system. An aquaponic system is established at Fisheries Research Station, Sri Venkateswara Veterinary University, Undi, Bhimavaram, West Godavari district, Andhra Pradesh, India. The future purpose of our study is finding an optimized solution for the Aquaponics systems to produce qualitative (organic) and quantitative food with low production cost, conservation of water efficiently and eco-friendly. This study has covered the designs, theoretical and practical concepts of Aquaponics, ideal conditions, management strategies, compatible aquacultural and horticultural varieties and concept of balancing the unit. This publication will be a supplemental hand out for outreach, extension, education and further research.

\section{Introduction}

Aquaculture is the fastest growing, potential food production sector. It is also recognised worldwide as one of the most efficient and promising contributor to the protein production. India being a tropical country with the second largest population in the world, it needs to ensure the nutritious diet for the growing population. The Indian Government under National Mission for protein supplement scheme is enhancing the supply of protein rich diet to the people. However, the increasing human population has crept into agriculture land for want of residential area, creating large scale problems for agriculture produce not only in India but also in the entire world. The human activities, degraded land, water, environmental, social and economic problems drive the need for new, innovative and improved solutions for food production and consumption by the ever increasing 
population. So it is the need of the hour to focus on alternate techniques of farming which can ensure better production in lesser area and lesser time. In this context, Aquaponics is one of the best technique and is the future food production system. Aquaponics is a recirculatory aquaculture systems for food production utilizing aquaculture and hydroponics to cultivate fish and horticultural varieties without soil. Recirculating systems are designed to raise large quantities of Fish in relatively small volume of water by treating the water to remove toxic waste products and then reusing it. In the process of reusing the water many times, nontoxic nutrients and organic matter accumulate. These metabolic by products need not be wasted if they are channelled into secondary crops that have economic value or some way benefit the primary fish production systems. The systems that grow additional crops by utilizing by-products from the production of the primary species, are referred to as integrated systems. If the secondary crops are aquatic or if terrestrial plants grown in conjunction with fish, this integrated system is referred to as Aquaponic system. It is an ecofriendly inexpensive symbiotic cycle between fish and plants.

Plants grow rapidly in response to dissolved nutrients that are excreted directly by fish or generated from the microbial breakdown of fish wastes. Using this criterion culinary herbs are the best choice as they grow very rapidly and command high market price.

\section{Materials and Methods}

\section{In aquaponic system}

\section{Various System Designs}

With the available resources the layout is designed in such a way that the water source for the aquaponic system come from the fish tank and is eventually returned to its source of origin. Four trials are carried out by establishing a small scale/domestic aquaponic units with recirculating aquaculture systems and hydroponics.

\section{Designs in Static waters}

\section{Raft Aquaponics or Floating bed}

Cement nursery of size $4.8 \times 3.8 \times 0.67$ (18.24 $\mathrm{m}^{2}$ ) is stocked with all male GIFT Tilapia of size $2.5 \mathrm{~cm}$ and $0.2 \mathrm{~g} @ 28 \mathrm{~m}^{2}$.

Polyurethane foam sheets are used as floating rafts which can accommodate 70 plant beds (10 lengthwise and 7 width wise).

Floating rafts are suspended on the surface static waters of fish tank.

Leafy vegetables like coriander, spinach, mint and Amaranthus are trailed (Fig. 1 and 2).

\section{Designs in Recirculatory Aquaculture Systems}

In Recirculatory Aquaculture System with the help of motor, water is circulated from fish tanks to plant beds and plant beds to fish tanks.

\section{Vertical System}

Cement nursery of size $4.8 \times 3.8 \times 0.67$ with capacity of $16.25 \mathrm{~m}^{2}\left(18.24 \mathrm{~m}^{2}\right)$ are stocked with all male Tilapia of size $2.5 \pm 0.20 \mathrm{~cm}$ and $0.2 \pm 0.42$ g @ $35 / \mathrm{m}^{2}$.(Fig. 3 \& Fig. 4)

This system is designed with PVC pipes framed parallely and positioned inclinedly, on the GI pipe stand which is erected on adjacent cement nursery.

The number of plant beds are 45 (5 pipes x 9 plant positions). Horticultural varieties like 
Tomato, Green chilli, Brinjal and Spinach are trailed by nutrient film technology for three months.

With the help of motor, the fish tank water is circulated from fish tank to plant beds on pipes and vice versa.

Nutrients are absorbed by plants, as the water passes on through.

\section{Horizontal System}

Cement nursery of size $4.8 \times 3.8 \times 0.67$ with capacity of $16.24 \mathrm{~m} 3(18.24 \mathrm{~m} 2)$ are stocked with Gift (Nile) Tilapia of size $13.5 \pm 5.0 \mathrm{cms}$ and $54.7 \pm 6.01 \mathrm{~g}$.

Similarly PVC pipes are framed parallely, poisoned horizontally in 6 rows on the fish tank. (Fig. 5, 6,7,8)

It receives water at one end and deliver at another end, which facilitated the plants to absorb the nutrients uniformly.

The number of plant beds are $78(13 \times 6)$.

Short duration horticulture varieties like Tomato, green chilli, Brinjal and Spinach are trailed by nutrient film technology for three months.

\section{Aquaponics unit in commercial scale}

Infrastructure of Aquaponics unit is established with 4 fish tanks $(4 \mathrm{~m} \times 5 \mathrm{~m} \times$ $1.5 \mathrm{~m})$ size and 24 plant beds, each bed with 3 rows again (Fig.9).

Twenty four plant beds (Fig.10) are sowed with short duration horticultural varieties like tomato, Spinach, Cucumber, Brinjal, green chillies, Mint, cauliflower, rib and bottle gourds, lady fingers and floriculture varieties like Chrysanthimum and Mari gold etc. (Fig.
12--20.). The four fish tanks (Fig.11) are trailed with various species like Carps, Air breathing fishes, Roopchand and Tilapia@50 $/ \mathrm{m}^{2}$. (Fig. $11 \& 21$ )

With the help of motors, the nutrient water from fish tanks is circulated from tanks to sump, through the plant beds, where in the plants absorb nutrients. The nutrient free water from sump is again recirculated to the fish tanks.

Harvesting and production (fig. No. 12-21 \& 22)

\section{Stocking}

\section{Plants}

Stocking of the plants should be in proportion to the nutrient release from fish ponds. Higher plant densities often mean that the yield per plant will be lower while producing a higher yield per acre. Stocking density is 12 plants / $\mathrm{m}^{2}$ for spinach and tomatoes, 20-25/ $\mathrm{m}^{2}$ for leafy green plants and 4-8 plants / $\mathrm{m}^{2}$ for fruiting vegetables respectively.

\section{Fish}

The stocking density is an important aspect for fish growth for several reasons. Water quality decreases proportionally when stocking densities are increased, in part due to a higher production of waste, increasing the levels of potentionally toxic substances, such as ammonia and nitrite. Another reason fish health is compromised when stocking densities are increased i.e. because higher stocking densities result in more consumption of oxygen and a lack of oxygen will result in stunted growth and reduced fish health. Under stocking the system however will result in a lower feed conversion ratio and reduce the efficiency of the system. Base on aeration and mechanical filtration, permits high stocking 
densities, but stocking density of $15-20 \mathrm{~kg} /$ 1000 liters is optimum.

\section{Principle in working process of Aquaponics system}

The integration of recirculatory system and hydroponicsin one production system works as mutual benefit for both systems, as the nutrients requirements is fulfilled by the disposing of nutrient rich fish waste from the Aquaculture unit (thus there is no need for nutrient media). The fish waste provides all nutrients solutions for plant growth and this nutrient rich effluent is used to irrigate hydroponic bed and fertilize its plant crops at the same time. The filteration of the water is done by the hydrophonic unit as the plants absorb the nutrients and filter the water through the sand filter so this media based hydrophonic system serves as an aerobic biofilter that is generally used in RAS systems, converting ammonia to nitrate. The ammonia is converted by denitrifying bacteria in the hydrophonic grow bed, into forms readily up taken by plants for energy and growth. Essentially the hydrophonic bed and its crops serve as a bio filter for the fish. Waste water is cleaned before it is returned back into the fish tank. Thus, the anaerobic (denitrification) filter used in RAS is largely replaced with a hydroponic plant production system. Out of the total nitrogen input used into the system as feed, upto $30 \%$ may be captured as fish flesh and $40 \%$ or more may be captured as plant biomass. The balance is lost as nitrogen gas or as solids, which may be used as fertilizer in a garden (Fox et al., 2013). Higher levels of nutrients capture may be possible with additional separate biofilteration (Christopher S et al., (2015), Surner, et al., (2015), Sharma, et al., 2018). Further, the complex mix of nitrifying bacteria, rhizobacteria, fungi and microplankton in the recirculated water appears to benefit the plants due to both positive interactions at root level, and the higher resilience of the system against some plants pathogens (Savidov, 2005).

\section{Results and Discussion}

Each design has its own advantages and disadvantages, all with different component styles to suit the needs of each method for different seasonal vegetable production.

Comparatively Aquaponics system consumes only $10 \%$ of amount of water that is used in traditional farming (Savodov, et al., 2018). It can be safely mentioned as the most water efficient natural intensive food production system. In the process of reusing the water many toxics, non toxic nutrients and organic matter accumulate and when these are channeled into secondary crops of high economic value, will benefit the primary fish production systems. The nutrient film obtained on nitrification, was passed on to the plants for taking of the nutrients.

\section{Water Quality Parameters management}

Water is the life blood of an aquaponic system. It is the medium through which the plants receive their nutrients and the fish receive their oxygen. It is very important to understand the water quality and basic water chemistry in order to properly manage aquaponics. The key factors for maintaining healthy bacteria are water temperature, ph, dissolved oxygen total nitrogen concentration and hardness and adequate surface area on which the bacteria grow.

Water analysis will provide information on the balance of the system also. High ammonia or nitrite indicates insufficient biofilteration, low nitrate indicates too many plants or not enough fish, increasing nitrate is desirable and indicates adequate nutrients for the plants (Pantanella, 2012). Hence knowing the effects of each parameter on fish, plants and bacteria 
is crucial. Below is the tabular form exhibiting the range of parameters, their tolerance levels and the mean data recorded weekly during experimentation. (Table.1)

\section{Nutrition and Feed Management}

Successful aquaponic systems are balanced. The feed rate ratio is the guideline to balance the amount of fish feed to plant growing area, which is measured in grams of daily feed per square meter of plant growing space. Plants have different nutritional requirements, for instance the leafy green vegetables require more nitrates than the fruiting plants. The feed rate ratio for leafy vegetables is $40-50 / \mathrm{m}^{2} /$ day and the fruiting vegetables require 50-80 $\mathrm{g} / \mathrm{m}^{2} /$ day (Pantanella et al., 2012). Standard manufactured fish feed pellets are supplied as they are a whole feed containing the correct balance of proteins, carbohydrates, fats, vitamins and minerals. Protein is the most important component for building fish body mass. The omnivorous fish such as tilapia, common carp and Magur, Clarias batrachus are fed with $32 \%$ protein feed. Carnivorous fish like snakeheads are fed with 40-42\% protein feed. Neither under feeding nor over feeding is done. The left out /uneaten feed is removed after 30 minutes to reduce risks of ammonia or hydrogen sulphide toxicity.

\section{Health Management}

Daily health monitoring of the fish and the plants is done, which will provide valuable feedback on the balance of the system. Disease, nutritional deficiencies and death are symptoms of an unbalanced system.
As flowering and fruiting of plants were observed, it indicates that the nitrate and other nutrients which were obtained from feed rate ratio seems to be sufficient and the system is also symbiotically balanced with the fish, plant and bacteria/microbes. No disease and mortality are observed in the system during experimentation, which indicates that the system is well balanced.

\section{Harvesting and Production}

The below mentioned table is exhibiting the growth performance and production (Table 2).

Tilapia, carps and cat fishes are highly suitable for Aquaponics in the tropical regions.

Graphical representation of the production rate of Horticulture varieties

Leafy vegetables like spinach, lettuce, cabbage are good crops for Aquaponic systems with Nile Tilapia because it can be produced in a short period and as a consequence the pest pressure is also relatively low. Unlike the fruiting crops a high proportion of the harvested biomass is edible. Hence this combination may be prioritized (Fig. 22).

To utilize the nutrients more in amount from the water effluent of aquaculture unit, the aquaponic unit should be dominated by the hydrophonic system (Radhakrishnan et al., 2019). To improve the water flow and minimize the dead areas it is better to have circular tanks for fish rearing. In such a system Nile Tilapia (Oreochromis niloticus) can be stocked at up to $60-70 \mathrm{~kg} / \mathrm{m}^{3}$. 
Table.1 Water quality parameters

\begin{tabular}{|c|c|c|c|c|}
\hline S.No. & Various Parameters & Ideal Range & $\begin{array}{c}\text { Tolerance } \\
\text { Range }\end{array}$ & Recorded in Trails \\
\hline $\mathbf{1 .}$ & $\mathrm{pH}$ & $6.8-7.8$ & $6-8.5$ & $7.8-8.0$ \\
\hline $\mathbf{2 .}$ & Water Temperature & $24-32^{\circ} \mathrm{C}$ & $22-32^{\circ} \mathrm{C}$ & $24-32^{\circ} \mathrm{C}$ \\
\hline $\mathbf{3 .}$ & DO & $5-8 \mathrm{mg} / 1$ & $4-6 \mathrm{mg} / \mathrm{l}$ & $4.5-5.5 \mathrm{mg} / 1$ \\
\hline $\mathbf{4 .}$ & Ammonia & $0 \mathrm{mg} / \mathrm{l}$ & $<3 \mathrm{mg} / \mathrm{l}$ & $<0.08 \mathrm{mg} / \mathrm{l}$ \\
\hline $\mathbf{5 .}$ & Nitrite & $0 \mathrm{mg} / 1$ & $<1 \mathrm{mg} / \mathrm{l}$ & $<0.06 \mathrm{mg} / 1$ \\
\hline $\mathbf{6 .}$ & Nitrate & $5-150 \mathrm{mg} / \mathrm{l}$ & $<400 \mathrm{mg} / \mathrm{l}$ & $160-180 \mathrm{mg} / \mathrm{l}$ \\
\hline $\mathbf{7 .}$ & Hardness & $140-350 \mathrm{mg} / 1$ & $60-500 \mathrm{mg} / 1$ & $80-380 \mathrm{mg} / 1$ \\
\hline $\mathbf{8}$ & Alkalinity & $60-160 \mathrm{mg} / 1$ & $60-200 \mathrm{mg} / 1$ & $120-150 \mathrm{mg} / 1$ \\
\hline
\end{tabular}

Table.2 Growth rate of commercial fish varieties under experimentation

\begin{tabular}{|c|c|c|}
\hline S. No. & Variety of fish sps. & Growth rate / production \\
\hline 1. & Cyprinus carpio & $600 \mathrm{~g} / 6-7$ months \\
\hline 2. & Labeo rohita & $650 \mathrm{~g} / 6-8$ months \\
\hline 3. & Oreochromis niloticus & $680 \mathrm{~g} / 6-9$ months \\
\hline $\mathbf{4 .}$ & Channa striatus & $400 \mathrm{~g} / 8-10$ months \\
\hline 5. & Clarias batrachus & $190 \mathrm{~g} / 4-6$ months \\
\hline
\end{tabular}

Fig.1

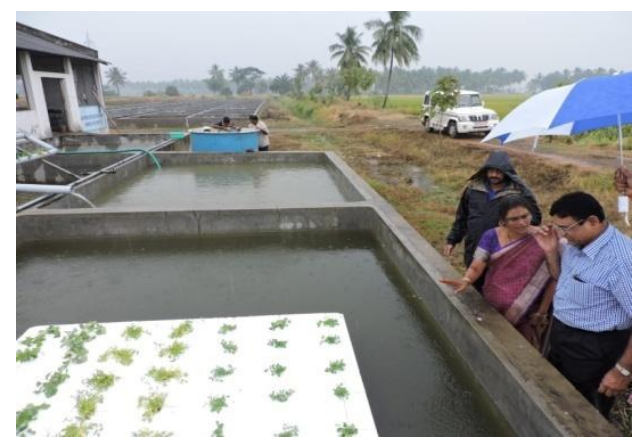

Fig.3

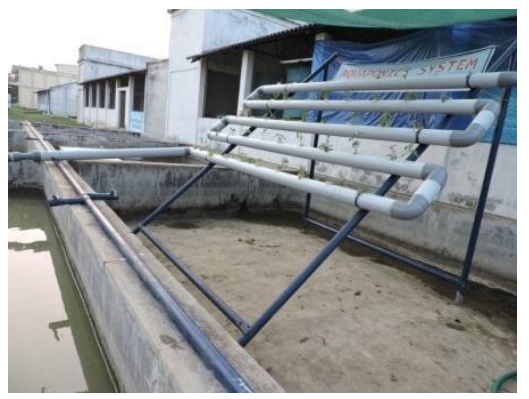

Fig.2

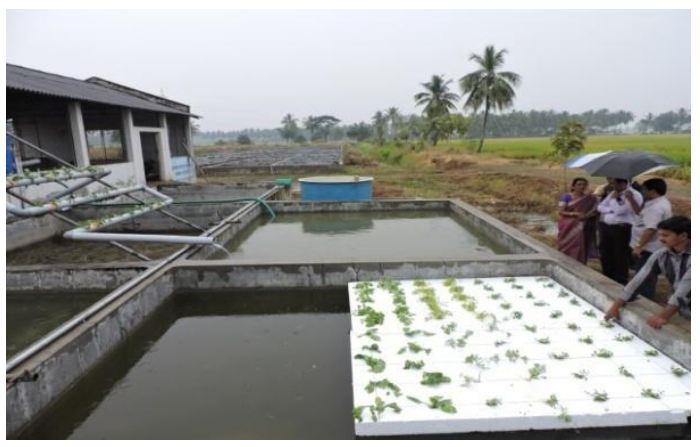

Fig.4

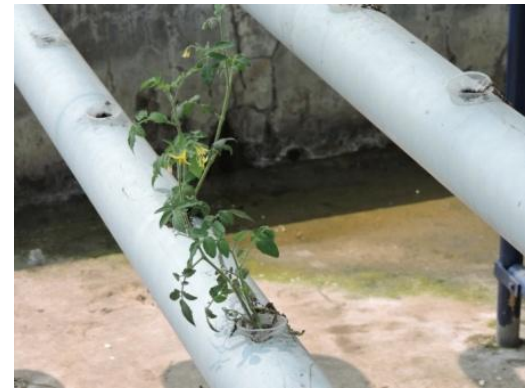


Fig.5

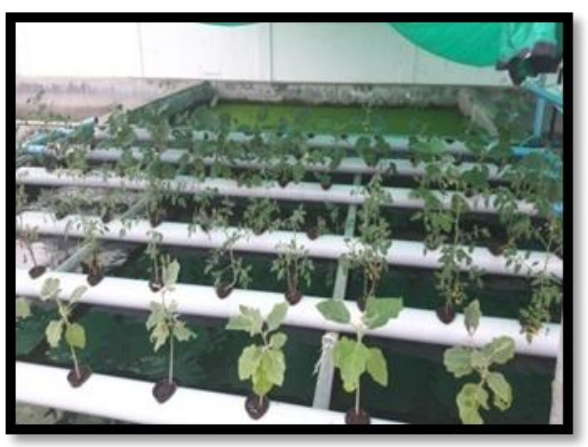

Fig.7

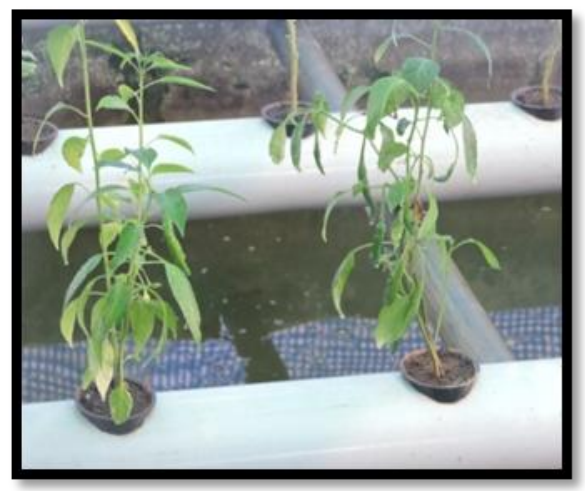

Fig.9

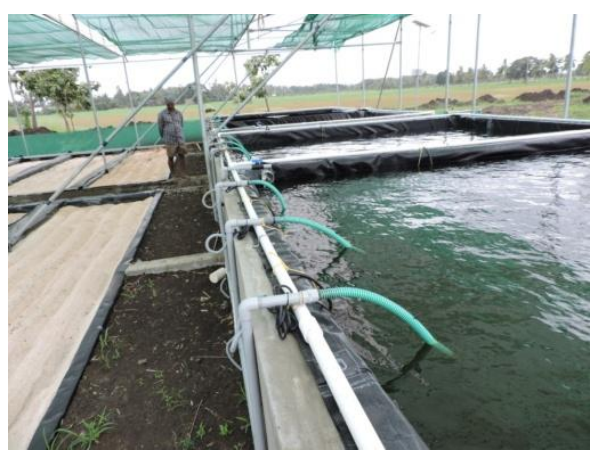

Fig.6

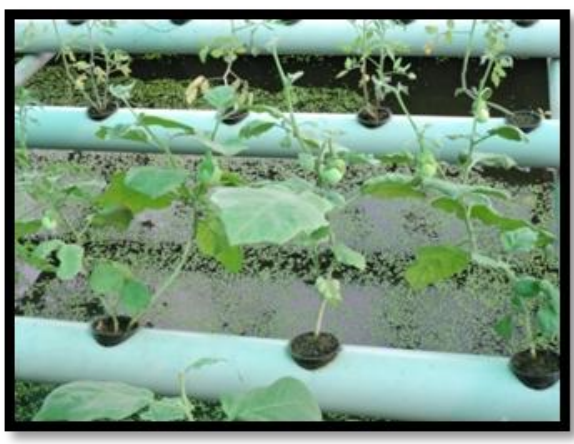

Fig.8

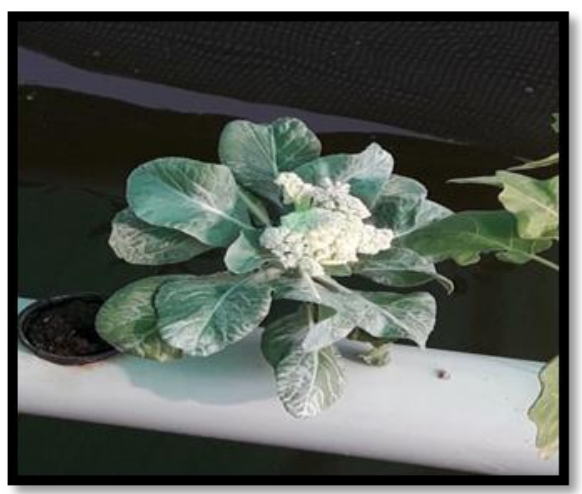

Fig.10

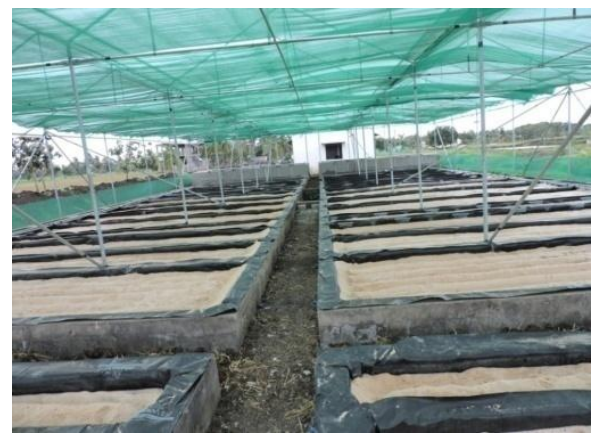


Fig.11

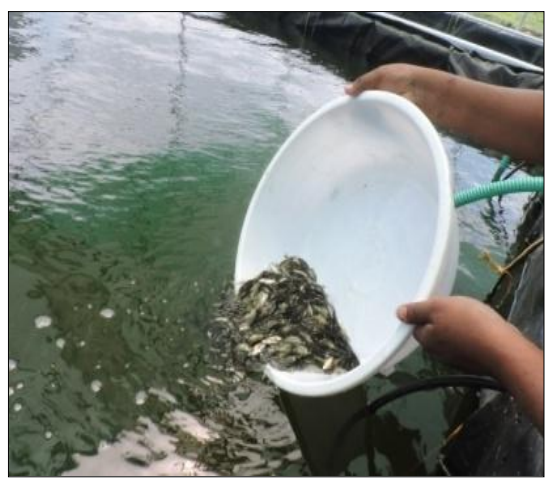

Fig.12

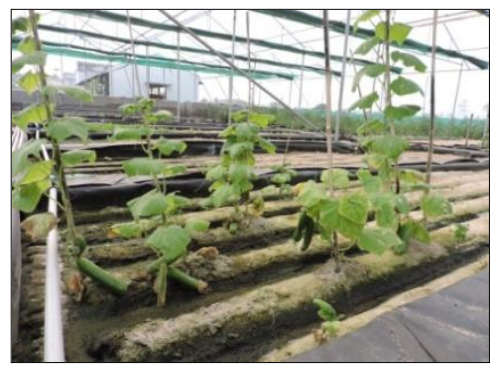

Fig.14

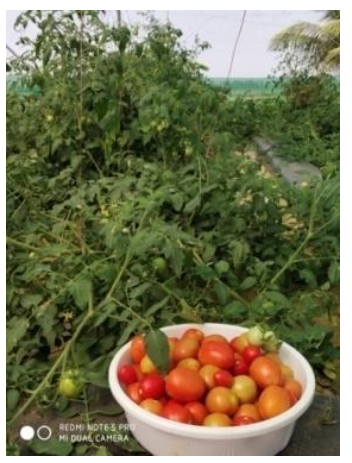

Fig.15

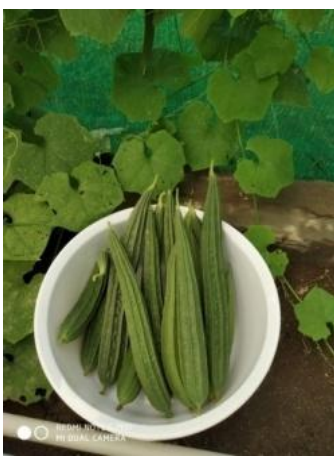

Fig.13

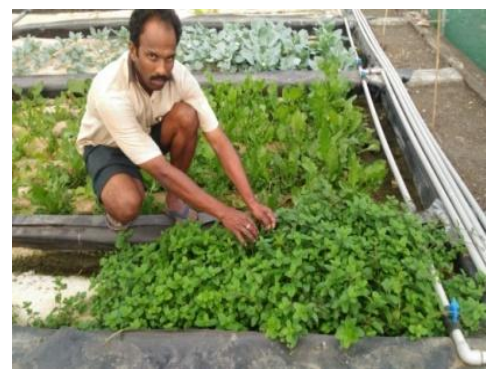

Fig.16

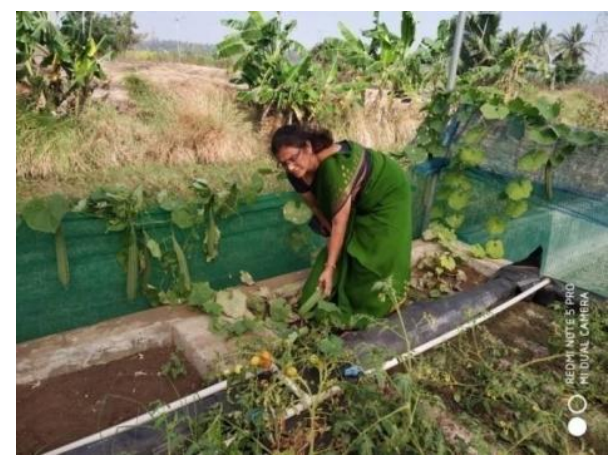


Fig. 17

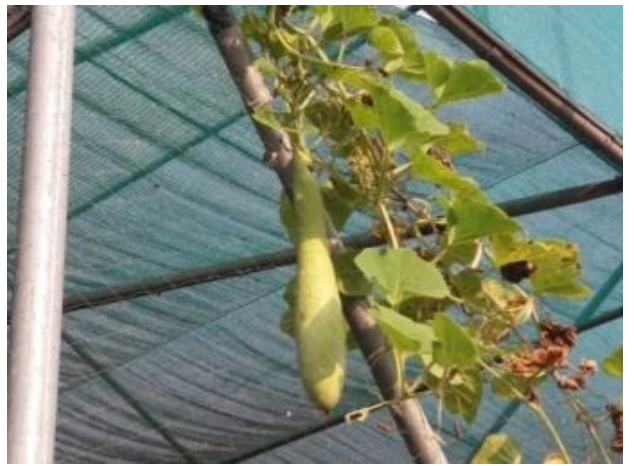

Fig. 18

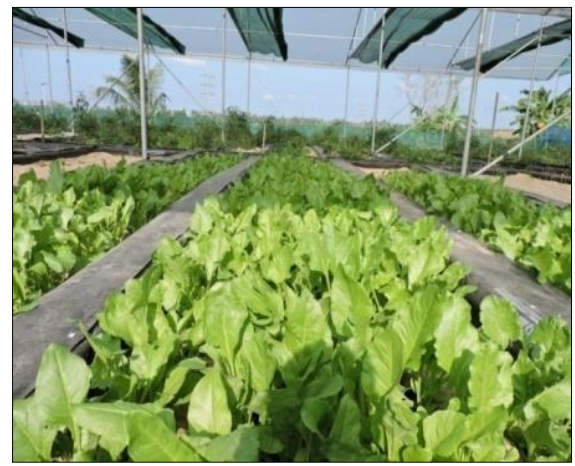

Fig. 19

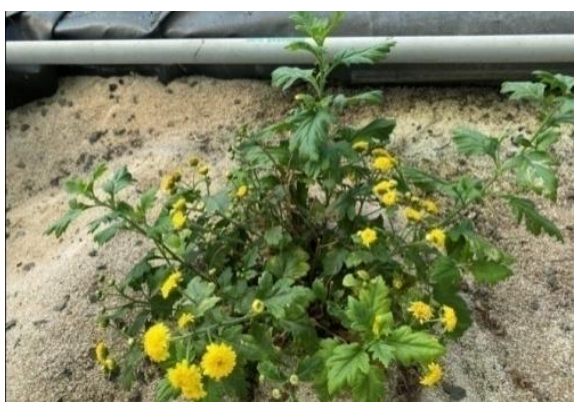

Fig. 20

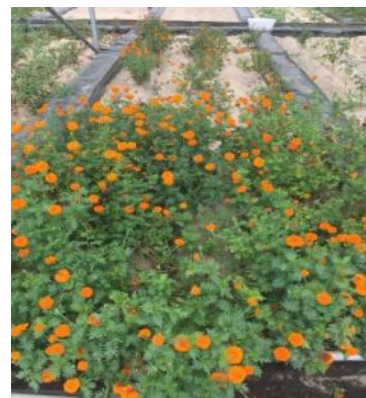

Fig. 21

Fig. 22

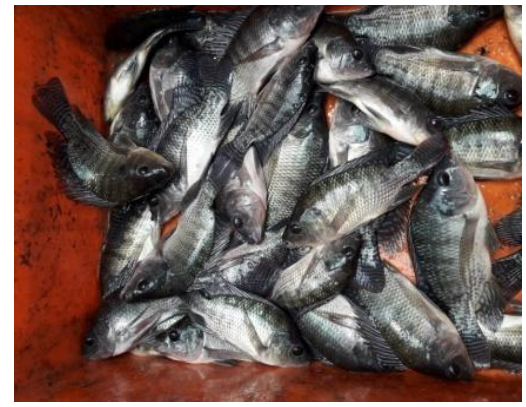

\section{Production rate / 3 months.}

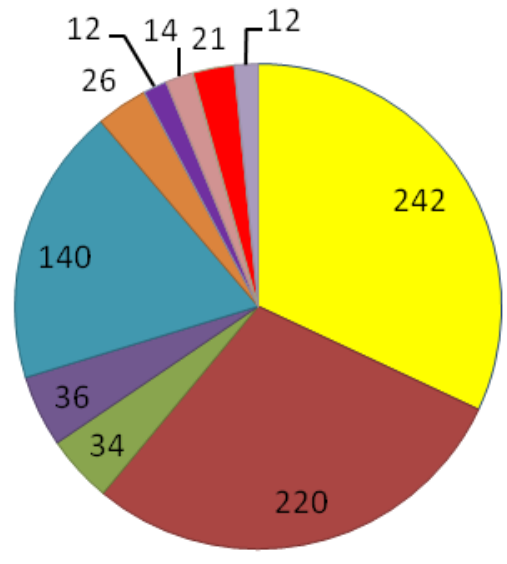

$\square$ Leafy vegetables / spinach

a Tomatoes

- Cauliflower

Bottle gourd

aib guard

$\square$ Brinjal / egg plant

- Mint

Green chillies

n Cucumber

Aquaponics is the integration of re-circulating aquaculture and hydroponics in system with sustainable and intensive food production. It addresses many issues in the system. Two agricultural products (fish and vegetables) are produced from one nitrogen source (fish 
food). It is extremely water efficient and disease free system. It does not require soil, fertilizers or chemical pesticides, antibiotics, herbicides or growth hormones and also much of the man power. Higher yields and qualitative (organic) production is assured throughout the year. Cost of production is much less comparatively, if solar power is used, the cost of production is still reduced. It can be set at backyard, roof top, balcony and non arable lands. It is the future food production system, irrespective of developed as well as under developed countries as it produces $100 \%$ organic food.

\section{References}

Christopher Somerville et al., 2015; small scale aquaponics food production, FAO Fisheries and Aquaculture Technical Paper 589.

Fox B et al., 2013; Toward lower-cost, More Rliable, Pacific- Friendly Aquaponic for the Pacific Islands Region: Review of opportunities and constraints Secretariat of the Pacific community Aquaculture, September $23^{\text {rd }}-27^{\text {th }}$, Rarotonga, Cook Islands, 2013.

Pantanella E, Cardarelli M, Colla G, Rea E, Marcucci. A. Aquaponicsvs Hydroponics 2012; Production and quality of Lettuce; Crop, acta Horti. 927: 887-893.

Radhakrishnan G et al., 2019; Impact of Hydroponics: Present and Future Perspective for farmer's welfare, Intl. Journal of Environment, Science and Technology vol. 5, Issue 2, pp:19-26.

Savidov N. et al., 2018, Aquaponics: A boon for income generation in water deficient areas of India like Rajasthan. Intl. Journal of Fisheries and Aquatic studies, 6 (6): 170-173.

Surner S. R et al., 2015; Aquaponics: Innovative farming, Intl Journal of Fisheries and Aquatic studies; 2 (4): 261-263.

\section{How to cite this article:}

Suguna, T. 2021. Aquaponics Systems: Future Food Production System. Int.J.Curr.Microbiol.App.Sci. 10(11): 397-406. doi: https://doi.org/10.20546/ijcmas.2021.1011.045 